\title{
Comportamento ingestivo e consumo de forragem por cordeiras em pastagem de milheto recebendo ou não suplemento
}

\section{Felipe Jochims ${ }^{1}$, Cleber Cassol Pires ${ }^{2}$, Letieri Griebler ${ }^{3}$, Anderson Michel Soares Bolzan ${ }^{3}$, Felipe Dotto Dias ${ }^{3}$, Diego Barcelos Galvani ${ }^{4}$}

\author{
${ }^{1}$ Programa de Pós-graduação em Zootecnia, Universidade Federal do Rio Grande do Sul (UFRGS). \\ 2 Departamento de Zootecnia, UFSM. \\ ${ }^{3}$ Curso de Zootecnia, UFSM. \\ ${ }^{4}$ Programa de Pós-graduação em Ciência Animal e Pastagens, Universidade de São Paulo (ESALQ/USP).
}

RESUMO - Avaliaram-se o comportamento ingestivo e o consumo de matéria seca de cordeiras recebendo diferentes tipos de suplemento em pastagem de milheto (Pennisetum americanum (L.) Leeke). Foram utilizadas 24 cordeiras com peso inicial de 30,2 \pm 2,6 kg, distribuídas em três estratégias alimentares: pastagem de milheto exclusivamente; pastagem de milheto e suplementação com farinha de mandioca; e pastagem de milheto e suplementação com glúten de milho. Os suplementos foram fornecidos na quantidade de $1 \%$ do PV. Foram avaliados, em três datas, os tempos diários (min/dia) de pastejo, ruminação e ócio e a taxa de bocados (boc/min) das cordeiras. O consumo de matéria seca (CMS) foi estimado pela relação entre a produção fecal e a indigestibilidade da matéria seca e a digestibilidade da MS, pelo método in vitro. A estimativa da excreção fecal foi realizada utilizando-se óxido de cromo como marcador externo. O delineamento experimental foi o inteiramente casualizado, com três estratégias alimentares, duas repetições de área e quatro animais-teste por repetição. O fornecimento de suplementos diminuiu o tempo de pastejo diário, a taxa de bocados e a massa de bocado. A ingestão de pasto foi menor entre as cordeiras que receberam glúten de milho que entre aquelas mantidas exclusivamente a pasto, todavia, a ingestão total de MS foi maior quando fornecidos os suplementos (947 g para suplementação com glúten de milho; $907 \mathrm{~g}$ para suplementação com farinha de mandioca; e 652 g para pastagem exclusiva). Cordeiras em pastagem de milheto sem suplementação permanecem mais tempo em pastejo.

Palavras-chave: farinha de mandioca, glúten de milho, massa de bocado, taxa de bocado, tempo de pastejo

\section{Feeding behavior and forage intake of ewe lambs on pearl millet pasture with or without supplementation}

\begin{abstract}
The feeding behavior and dry forage intake of ewe lambs receiving different types of supplementation on pearl millet (Pennisetum americanum (L.) Leeke) pasture was evaluated. Twenty-four ewe lambs with $30.2 \pm 2.6 \mathrm{~kg}$ mean initial body weight (BW), distributed in three feeding strategies: grazing on pearl millet pasture; grazing on pearl millet pasture supplemented with cassava meal; and GL - grazing on pearl millet pasture supplemented with corn gluten meal. Supplements were provided in the amount of $1 \%$ of BW. The daily times (min/day) spent grazing, ruminating and idling, and the biting rate (bites/min) were evaluated on three dates. The dry matter intake (DMI) was estimated from the relationship between the fecal production (FC, g/day) and dry matter indigestibility by the in vitro method. The fecal excretion was estimated using chomium oxide as an outside marker. A randomized complete design was used, with three feeding strategies, two area replications and four tester animals per replication. Providing supplements decreased the daily grazing time, bite rate and bite mass. Pasture intake was lower among ewe lambs that received corn gluten than for those kept exclusively on pasture; however, dry matter total intake was higher when supplement fed (947 g for corn gluten supplementation; $907 \mathrm{~g}$ for cassava meal supplementation; and $652 \mathrm{~g}$ for exclusive pasture). Ewe lambs on pearl millet pasture without supplementation keep on grazing for more time.
\end{abstract}

Key Words: bite mass, bite rate, cassava meal, corn gluten meal, grazing time

\section{Introdução}

Para a eficiente exploração da pastagem, é necessário conhecer as relações existentes na interface planta-animal, o que envolve o estudo de como as condições de pastejo interferem no comportamento ingestivo dos ruminantes e no seu desempenho, de forma a identificar condições de manejo adequadas à categoria animal e ao sistema de produção adotado.

Recebido em 19/5/2008 e aprovado em 16/3/2009.

Correspondências devem ser enviadas para: felipejochims@yahoo.com.br 
A produção animal em pastagens depende de fatores relacionados à planta, ao animal, à quantidade e à forma como a forragem apresentada, determinando diferentes respostas em termos de consumo de forragem e desempenho. Essas respostas incluem estratégias de pastejo para cada estrutura da pastagem (Carvalho et al., 2001). A quantidade de forragem consumida é o principal fator determinante do desempenho animal (Ungar, 1996), assim, os fatores que afetam o consumo influenciarão fortemente o desempenho.

A qualidade da dieta consumida pelos animais depende da possibilidade e capacidade do animal em selecionar uma dieta de alto valor nutritivo (Prache \& Peyraud, 1997), e essa capacidade é determinada pelo padrão de pastejo do animal, por meio da seleção da dieta, do tempo de pastejo, da taxa de bocados e da massa do bocado, que é a variável mais importante na determinação do consumo de animais em pastejo e a mais influenciada pela estrutura do dossel forrageiro (Hodgson, 1985).

Quando o pasto constitui toda a dieta dos animais, uma disponibilidade de forragem limitante proporcionaria aumento em alguns dos componentes do comportamento ingestivo, como a taxa de bocados e/ou tempo de pastejo. Noentanto, quando uma parte da dieta dos animais é constituída por concentrado, existe maior aporte de nutrientes pelo suplemento e, dessa forma, o comportamento ingestivo dos animais pode sofrer modificações (Barton et al., 1992).

Considerando que o fornecimento de suplementos modifica a forma como as cordeiras interagem com a pastagem, este trabalho foi conduzido com o objetivo de avaliar o comportamento ingestivo de cordeiras desmamadas, na fase da recria, em pastagem de milheto (Pennisetum americanum (L) Leeke) sem suplementação, recebendo suplemento energético ou proteico de baixa degradabilidade ruminal.

\section{Material e Métodos}

O trabalho foi realizado no período de 6/11/2006 a 28/3/2007, em área pertencente ao Departamento de Zootecnia da Universidade Federal de Santa Maria, localizada na região fisiográfica da Depressão Central do Rio Grande do Sul. O solo pertence à unidade de mapeamento São Pedro e é classificado como Argisolo Vermelho Distrófico arênico (EMBRAPA, 1999). A região possui clima subtropical úmido (Cfa), conforme classificação de Köppen (Moreno, 1961).

A pastagem foi implantada por meio de plantio convencional em 6/11/2006, com densidade de semeadura de $50 \mathrm{~kg} /$ ha de semente de milheto (Pennisetum americanum
(L.) Leeke.), utilizando-se adubação de 200 kg/ha de NPK da fórmula 5-20-20 e adubação de cobertura de 135 kg/ha de nitrogênio na forma de ureia, distribuídos em três aplicações (2/2/2006; 27/2/2006; 15/3/2006). A área experimental foi de 0,8 ha subdividida em seis unidades experimentais de aproximadamente 0,135 ha mais uma área de 0,3 ha de milheto destinada aos animais reguladores da massa de forragem (MF). O período de utilização da pastagem foi de 23/1/2006 a 28/3/2006, totalizando 63 dias de pastejo.

As estratégias alimentares foram pastagem exclusiva; suplementação com farinha de mandioca na proporção de $1 \%$ do peso vivo (PV); e suplementação com glúten de milho (protenose) na proporção de 1\% do PV. O suplemento foi fornecido diariamente, em gaiolas individuais, onde os animais permaneciam por um período de 50 minutos, às $9 \mathrm{~h}$ da manhã (Medeiros et al., 2007).

Foram utilizadas quatro cordeiras-teste por repetição, produtos do cruzamento entre as raças Texel e Ile de France, com idade e peso médio inicial de $177 \pm 12$ dias e 30,2 \pm 2,6 kg, respectivamente, e um número variável de animais reguladores. A infestação dos animais por endoparasitas foi monitorada pelo método FAMACHA (Malan \& Van Wyk, 1992) e o controle feito sempre que necessário. O controle de foot-rot foi feito com passagens em pedilúvio, utilizando sulfato de zinco a 10\% (Scremini et al., 1981), sempre que os animais apresentavam os sintomas da enfermidade.

O método de pastejo adotado foi de lotação contínua com um número variável de animais reguladores (Mott \& Lucas, 1952). Para manter massa de forragem (MF) média de $2000 \mathrm{~kg} /$ ha de MS, o ajuste da lotação foi feito a cada 10 dias, utilizando-se o método proposto por Heringer \& Carvalho (2002). O pastejo foi de 24 horas e todos os animais tiveram acesso irrestrito a água e suplementação mineral.

Para determinação da massa de forragem, expressa em kg/ha de MS, foi utilizada a técnica de estimativa visual com dupla amostragem com cinco cortes rentes ao solo e 20 estimativas visuais (Gardner, 1986), realizada a cada dez dias. A forragem proveniente dos cortes foi homogeneizada e dividida em duas subamostras, uma para a determinação do teor de MS do pasto e outra destinada à separação botânica e estrutural (colmos+bainhas, lâminas foliares, material morto e outras espécies). As amostras foram pesadas e secas em estufa com circulação forçada de ar a $55^{\circ} \mathrm{C}$, por no mínimo 72 horas, até atingirem peso constante. Por meio da separação manual dos componentes, foram determinadas a participação percentual de lâminas foliares e colmos+bainhas e a relação lâmina/colmo. 
A massa de forragem multiplicada pelo percentual de material verde na pastagem resultou na massa de forragem verde (MFV). A massa de lâminas foliares (MLF) foi obtida multiplicando-se a massa de forragem pela porcentagem de lâminas foliares presentes no pasto. A taxa diária de acúmulo de forragem (TxAC) foi determinada de acordo com Klingman et al. (1943), utilizando-se três gaiolas de exclusão ao pastejo. A oferta de forragem (kg de MS/100 kg de PV) foi obtida pela divisão da disponibilidade diária de forragem ((MF/número de dias do período) + TxAC) pela carga animal (CA), e este valor, posteriormente multiplicado por 100. A oferta de lâminas foliares verdes (OLFV) foi obtida por meio da multiplicação da oferta de forragem pelo percentual de lâminas foliares na pastagem.

A determinação da digestibilidade in vitro da matéria orgânica (DIVMO), digestibilidade in vitro da matéria seca (DIVMS) e da composição bromatológica da forragem aparentemente consumida pelos animais foi feita a partir de análise laboratorial de amostras de forragem colhidas por meio de simulação de pastejo dos animais-teste de cada piquete. Na mesma ocasião, foram realizados os mesmos procedimentos em amostras dos suplementos utilizados no experimento. A amostra colhida foi pesada e seca em estufa de circulação forçada de ar a $55^{\circ} \mathrm{C}$ por 72 horas, posteriormente foi moída em moinho tipo Willey e encaminhada para análise. Os itens avaliados foram: digestibilidade in vitro da matéria orgânica (DIVMO), digestibilidade in vitro da matéria seca (DIVMS), proteína bruta (PB), fibra em detergente neutro (FDN), de acordo com as técnicas descritas por Tilley \& Terry (1963), AOAC (1995) e Goering \& Van Soest (1970), respectivamente.

A pesagem das cordeiras foi realizada a cada 21 dias, com 12 horas de jejum prévio de sólidos e líquidos. A taxa de lotação (TXLOT) expressa em kg/ha de PV, foi obtida da seguinte forma: TXLOT $=$ (peso médio animais-teste + (peso reguladores $\times$ dias de permanência)) $/ \mathrm{N}^{\circ}$ dias do período.

O consumo de matéria seca (CMS) foi estimado pela relação entre a produção fecal (PF, g/dia) e a indigestibilidade da matéria seca (IDMS): CMS (g/dia) = PF/IDMS; em que, IDMS = 1-digestibilidade da MS. A digestibilidade da MS de amostras de simulação de pastejo foi estimada pelo método in vitro de Tilley \& Terry (1963). Por sua vez, a estimativa da excreção fecal foi realizada mediante o uso de óxido de cromo $\left(\mathrm{Cr}_{2} \mathrm{O}_{3}\right)$ como marcador externo. Para isso, em cada período, cápsulas contendo 1 grama de $\mathrm{Cr}_{2} \mathrm{O}_{3}$ foram administradas diariamente, uma vez ao dia por oito dias consecutivos, imediatamente antes de os animais receberem o suplemento (9 horas). No último dia de fornecimento do indicador, amostras de fezes foram coletadas diretamente do reto dos animais, em intervalos de 4 horas, ao longo de um período de 24 horas.

As amostras de fezes foram pesadas e imediatamente congeladas. Posteriormente, foram secas em estufa com circulação forçada de ar a $55^{\circ} \mathrm{C}$ por cinco dias e trituradas em moinho tipo Willey provido de peneira com orifícios de $1 \mathrm{~mm}$. As amostras foram, então, homogeneizadas por animal e por período, constituindo amostras compostas. Para determinação da concentração de óxido de cromo nas fezes, aproximadamente $0,5 \mathrm{~g}$ de amostra parcialmente seca foi pesada, colocada em Becker com capacidade para $25 \mathrm{~mL}$ e queimada em mufla a $550^{\circ} \mathrm{C}$ por 3 horas. Posteriormente, foram adicionados $5 \mathrm{~mL}$ de uma solução contendo $10 \mathrm{~g}$ de molibdato de sódio, $150 \mathrm{~mL}$ de água destilada, $150 \mathrm{~mL}$ de ácido sulfúrico e $200 \mathrm{~mL}$ de ácido perclórico (Czarnocki et al., 1961). A solução foi coberta com bola de vidro e colocada em uma chapa quente a aproximadamente $200^{\circ} \mathrm{C}$. Depois que a solução passou de uma cor esverdeada para amarelo-alaranjada, o conteúdo foi filtrado e totalmente transferido para um balão volumétrico, lavando-se o Becker várias vezes com água destilada, até completar o volume de $100 \mathrm{~mL}$. Destas amostras, uma alíquota foi coletada para determinação de cromo por espectrofotometria de absorção atômica. A curva-padrão foi elaborada por tratar $100 \mathrm{mg}$ de óxido de cromo como as amostras de fezes. A produção fecal (PF) dos animais foi, então, calculada como: PF (g/dia) = indicador administrado (g/dia)/concentração do indicador nas fezes (g/kg de MS).

As taxas de substituição e de adição do consumo de suplemento sobre o consumo de pasto foram estimadas pelo cálculo proposto por Hodgson (1990), em que: substituição= (consumo de matéria seca (MS) de pasto dos animais não suplementados - consumo de MS de pasto dos animais suplementados)/consumo de MS do suplemento*100; adição = $($ consumo total de MS dos animais suplementados - consumo de MS do pasto dos animais não suplementados) / consumo de MS do suplemento*100.

As observações do comportamento ingestivo foram realizadas durante períodos de 24 horas, nos dias12 e 13/02/06; 5 e 6/03/06, 26 e 27/03/06. Foram empregados avaliadores treinados, cada um responsável pela observação de quatro animais-teste. As anotações foram feitas a cada dez minutos, por meio de observação visual (Jamieson \& Hodgson, 1979), com registro das atividades de pastejo, ruminação, ócio e taxa de bocados (tempo para realizar 20 bocados), conforme metodologia descrita por Hodgson (1982). O tempo gasto pelos animais na seleção e apreensão da forragem, incluindo os curtos espaços de tempo utilizados no deslocamento para a seleção da dieta, foi considerado 
tempo de pastejo (minutos/dia) (Hancock, 1953). O tempo de ruminação (minutos/dia) foi identificado pela cessação do pastejo e pela atividade de mastigação. O tempo de ócio (minutos/dia) foi considerado o período no qual o animal manteve-se em descanso (Forbes, 1988) e em outras atividades. O tempo de permanência no cocho, correspon-dente ao tempo para o consumo de suplemento, foi preestabelecido durante o período de adaptação dos animais, ou seja, de 50 minutos.

No cálculo da massa de bocado, dividiu-se o consumo diário de pasto, expresso em g/dia/animal, pelo total de bocados (taxa de bocado $\times$ tempo de pastejo; Jamieson $\&$ Hodgson, 1979). A massa de bocado foi obtida da seguinte forma: Ingestão de MS de pasto/dia, dividida pelo tempo de pastejo dos animais. O resultado obtido foi dividido pela taxa de bocados por minuto.

O delineamento experimental foi inteiramente casualizado com medidas repetidas no tempo, com três tratamentos e duas repetições, totalizando seis unidades experimentais. Para todas as variáveis estudadas, a unidade experimental foi constituída pelo potreiro. Os dados foram submetidos à análise de variância, cujo modelo incluiu os efeitos de tratamento, período, subsubparcela (animal-teste) e da interação tratamento × período, e ao teste F com nível de significância de 5\%. Quando detectadas diferenças significativas entre as médias, estas foram comparadas pelo teste de Tukey, também a 5\% de significância. Todas as análises foram realizadas pelo procedimento GLM do programa estatístico SAS (2001).

\section{Resultados e Discussão}

Não houve interação entre estratégias alimentares e períodos $(\mathrm{P}>0,05)$ para as massas de forragem $(\mathrm{MF})$, de forragem verde (MFV), de lâmina foliar verde (LFV), de forragem de outras espécies (MFO), a taxa diária de acúmulo de forragem (TxAC) e a relação folha/colmo (F/C), a taxa de lotação (TXLOT), a oferta de forragem (OF), a oferta de lâminas foliares verdes (OLFV) e a digestibilidade in vitro da matéria orgânica (DIVMO), da fibra em detergente neutro (FDN) e o teor de proteína bruta (PB) das amostras referentes à simulação de pastejo. Essas variáveis foram semelhantes $(\mathrm{P}>0,05)$ entre as estratégias alimentares e os períodos (Tabela 1).

Todos os animais foram submetidos à mesma massa de forragem, massa de forragem verde, LVF e MFO e os valores encontrados para essas variáveis indicam que não houve restrição ao consumo (Rattray et al., 1987). Não houve diferença entre os tratamentos para TxAC e a relação folha/colmo, com valores semelhantes aos relatados por Bremm et al. (2008).

A taxa de lotação, a oferta de forragem e a oferta de lâminas foliares verdes não diferiram entre tratamentos $(P>0,05)$ e os valores observados indicam que não houve limitação para a melhor colheita de forragem pelos animais (Adjei et al., 1980). A DIVMO e os teores de FDN e PB do pasto aparentemente consumido pelos animais, não diferiram entre os tratamentos $(\mathrm{P}>0,05)$, indicando que o fornecimento de suplemento proteico com baixa degradabilidade ruminal e de suplemento com carboidratos prontamente fermentáveis no rúmen não provocaram mudanças na seletividade dos animais ao pasto.

Houve diferença entre estratégias alimentares para tempo de pastejo ( $\mathrm{P}<0,05$; Tabela 2 ), uma vez que os animais que não receberam suplemento apresentaram maiores tempos diários de pastejo em relação àqueles sob suplementação, os quais não diferiram entre si $(\mathrm{P}>0,05)$. Segundo Krysl \& Hess (1993), a eficiência de colheita de nutrientes,

Tabela 1 - Características morfológicas da pastagem de milheto, taxa de lotação, oferta de forragem e oferta de lâmina foliar verde e características bromatológicas do pasto durante o período experimental

\begin{tabular}{|c|c|c|c|c|}
\hline \multirow[t]{2}{*}{ Item } & \multicolumn{3}{|c|}{ Estratégia alimentar } & \multirow[t]{2}{*}{$\mathrm{CV}(\%)$} \\
\hline & Farinha de mandioca & Glúten milho & Milheto & \\
\hline Massa de forragem (kg/ha de MS) & 2646 & 2530 & 2177 & 26,12 \\
\hline Massa de forragem verde (kg/ha de MS) & 2329 & 2153 & 1860 & 27,81 \\
\hline Massa de lâminas foliares (kg/ha de MS) & 672 & 478 & 439 & 60,02 \\
\hline MF outras espécies (kg/ha de MS) & 1024 & 1069 & 956 & 26,57 \\
\hline Taxa diária de acúmulo (kg/ha de MS) & 103 & 91 & 93 & 21,97 \\
\hline Relação folha/colmo & 1,02 & 0,77 & 0,81 & 26,11 \\
\hline Taxa de lotação (kg/ha dia de PV) & 1698 & 1607 & 1527 & 27,37 \\
\hline Oferta de forragem (kg MS/100 kg PV/dia) & 15,2 & 14,5 & 15,5 & 24,63 \\
\hline Oferta lâmina foliar verde (kg MS/100 kg PV/dia) & 2,2 & 1,5 & 1,4 & 70,45 \\
\hline DIVMO (\%) & 58,67 & 58,33 & 54,67 & 5,37 \\
\hline Fibra em detergente neutro $(\%)^{5}$ & 57,17 & 58,27 & 59,29 & 3,75 \\
\hline Proteína bruta do pasto $(\%)^{6}$ & 17,11 & 16,79 & 16,61 & 8,76 \\
\hline
\end{tabular}

DIVMO = digestibilidade in vitro da matéria orgânica do pasto; FDN = fibra em detergente neutro do pasto. 
Tabela 2 - Médias de tempo de pastejo, ruminação e ócio (minutos/dia) de cordeiras, em pastagem de milheto, durante 24 horas

\begin{tabular}{|c|c|c|c|c|c|}
\hline \multirow[t]{2}{*}{ Item } & \multicolumn{3}{|c|}{ Estratégia alimentar } & \multirow[t]{2}{*}{ CV (\%) } & \multirow[t]{2}{*}{$\operatorname{Pr}>F$} \\
\hline & $\mathrm{M}^{1}$ & $\mathrm{GL}^{2}$ & $\mathrm{MA}^{3}$ & & \\
\hline Pastejo (min/dia) & 492,06a & 419,94b & $398,72 b$ & 10,57 & 0,0001 \\
\hline Ruminação (min/dia) & 466,20 & 441,03 & 430,37 & 11,51 & 0,0584 \\
\hline Ócio (min/dia) & $488,26 b$ & $527,21 \mathrm{ab}$ & $562,02 \mathrm{a}$ & 16,05 & 0,0145 \\
\hline
\end{tabular}

Valores seguidos por letras minúsculas diferentes na mesma linha diferem $(\mathrm{P}<0,05)$ pelo teste Tukey.

${ }^{1}$ Sem suplemento; ${ }^{2}$ Glúten de milho; ${ }^{3}$ Farinha de mandioca.

ou seja, a quantidade de nutrientes colhida por unidade de tempo é maior quando os animais recebem suplemento, o que pode explicar a redução no tempo de pastejo desses herbívoros. O tempo de pastejo das cordeiras sob suplementação foi, em média, 20\% inferior ao daquelas que não receberam suplemento e seus valores totalizaram 6,6; 7,0 e 8,2 horas/dia para as cordeiras que receberam farinha de mandioca, glúten de milho e aquelas sem suplementação, respectivamente. A redução nos tempos de pastejo das cordeiras sob suplementação também pode ter sido ocasionada pelo mecanismo de regulação fisiológica, em que o consumo é mais provavelmente determinado por entraves metabólicos, relacionado à habilidade animal em utilizar nutrientes absorvidos (Illius \& Jessop, 1996).

O tempo de pastejo dos animais mantidos exclusivamente em pastejo foi menor que os valores descritos por Pedroso et al. (2004) para animais mantidos por 10,9 horas em pastagem de azevém. Os menores tempos de pastejo obtidos neste experimento ocorreram provavelmente devido à baixa qualidade do milheto em comparação ao azevém, provocando a saciedade física pelo enchimento do rúmen (Kozloski, 2002).

O aumento do tempo de pastejo, segundo Hodgson (1990), é uma estratégia comportamental dos animais detêm para compensar uma redução no consumo de pasto. No modelo proposto por esse autor, essa estratégia implicaria também aumento no tempo de ruminação e, apesar de ter sido observada tendência de os animais alimentados exclusivamente com milheto apresentarem maior tempo de ruminação ( $\mathrm{P}=0,0584)$, essa variável foi semelhante entre as estratégias alimentares estudadas ( $\mathrm{P}>0,05)$.

O tempo de ruminação é influenciado pela natureza da dieta e parece ser proporcional ao teor de parede celular dos volumosos (Van Soest, 1994), no entanto, o teor de FDN do pasto não variou significativamente entre as estratégias de alimentação (Tabela 1), o que provavelmente explica a semelhança no tempo de ruminação.

O tempo de ócio variou entre as estratégias alimentares $(\mathrm{P}<0,05)$ e foi maior nos animais sob suplementação com farinha de mandioca em comparação àqueles mantidos exclusivamente em pastejo e não diferiu $(\mathrm{P}>0,05)$ dos animais sob suplementação com glúten de milho. Segundo Hodgson (1990), quando o tempo de pastejo diminui, o tempo de ócio tende a aumentar.

Houve diferença $(\mathrm{P}<0,05)$ na taxa de bocados para todas as estratégias alimentares (Tabela 3). Os animais sob suplementação com farinha de mandioca realizaram a menor taxa de bocado e aqueles mantidos exclusivamente em pastagem, a maior taxa de bocados. A taxa e a massa de bocado não diferiram $(\mathrm{P}>0,05)$ entre os períodos de utilização da pastagem.

A menor taxa de bocados dos animais sob suplementação com farinha de mandioca foi compensada por um aumento na MsBOC, uma vez que as cordeiras colheram 38\% a mais de MS por bocado, diferindo $(\mathrm{P}<0,05)$ das demais estratégias de alimentação. Segundo Newman et al. (1994), animais a campo empregam diferentes estratégias para aumentar o consumo durante o pastejo, seja por meio da variação da massa do bocado, do aumento da frequência de bocados ou pelo aumento do tempo de pastejo. Os animais alimentados exclusivamente com milheto aumentaram em $16,4 \%$ a taxa de bocados em relação aos que recebiam farinha de mandioca.

Em situação de pastejo, a apreensão de pasto pode ser facilitada quando a massa de forragem não é limitante, visto que o consumo por bocado é influenciado pela resistência à ruptura do material, de forma que a massa do bocado pode estar limitada pela força máxima que o animal é capaz de exercer na apreensão do alimento (Prache \& Peyraud, 1997). Neste trabalho, a massa de forragem não foi limitante para

Tabela 3 - Valores médios de taxa de bocado, expressa em número de bocados por minuto, e de massa de bocado, expressa em $\mathrm{mg}$ de MS de pasto por bocado

\begin{tabular}{lcc}
\hline Estratégia alimentar & \multicolumn{2}{c}{ Item } \\
\cline { 2 - 3 } & $\begin{array}{c}\text { Taxa bocado } \\
\text { (boc/min) }\end{array}$ & $\begin{array}{c}\text { Massa bocado } \\
\text { (mg/MS) }\end{array}$ \\
\hline Farinha de mandioca & $34,12 \mathrm{c}$ & $57,35 \mathrm{a}$ \\
Glúten de milho & $36,04 \mathrm{~b}$ & $38,40 \mathrm{~b}$ \\
Milheto & $40,83 \mathrm{a}$ & $32,83 \mathrm{~b}$ \\
CV $(\%)$ & 5,98 & 13,99 \\
\hline
\end{tabular}

Valores seguidos por letras minúsculas diferentes na mesma coluna diferem $(\mathrm{P}<0,05)$ pelo teste Tukey. 
o consumo dos animais (Tabela 1), pois, segundo Poppi (1983) e Rattray et al. (1987), pastagens tropicais com valores inferiores a $1.800 \mathrm{~kg} /$ ha de MS dificultam o pastejo, limitando o consumo de pasto pelos cordeiros.

Uma explicação viável para a mudança na estratégia de pastejo seria de que os animais sob suplementação tiveram maior aporte de nutrientes e estavam menos dependentes da pastagem para atender suas exigências nutricionais, o que ocasionaria menor competição na procura por alimento, aumentando a seletividade dos animais quanto à escolha do local de pastejo (Provenza \& Lauchbaungh, 1999). Segundo Krysl \& Hess (1993), animais sob suplementação aumentam a eficiência de colheita de nutrientes do pasto, ocasionando menores tempos de pastejo. Essa teoria também pode explicar o comportamento da taxa de bocados dos animais sob suplementação com glúten de milho, pois houve diferença nessa variável e os valores foram intermediários aos encontrados para os animais sob suplementação com farinha de mandioca ou mantidos exclusivamente em pastagem.

Os valores de taxa de bocado são semelhantes aos dados observados por Bremm et al. (2008), em trabalho realizado com cordeiras em pastagem de milheto e superiores aos encontrados por Parente et al. (2007), que observaram valores médios de 24,38 bocados por minuto.

Os animais sob suplementação com glúten de milho consumiram menor quantidade de MS de pasto em relação àqueles que não receberam suplemento $(\mathrm{P}<0,05)$, porém não diferiram ( $\mathrm{P}>0,05$; Tabela 4 ) daqueles sob suplementação com farinha de mandioca. A ingestão de matéria seca de suplemento não diferiu $(\mathrm{P}>0,05)$ entre os animais que receberam suplemento.

Os resultados obtidos indicam que o aumento na MsBOC das cordeiras sob suplementação com farinha de mandioca compensaram a menor taxa de bocados (Tabela 3), não havendo diferença $(P>0,05)$ na ingestão de matéria seca de pasto entre os animais sob suplementação com farinha de mandioca e daqueles sem suplementação. As cordeiras sob suplementação com glúten de milho consumiram a menor quantidade de MS de pasto, diferindo significativamente daquelas sem suplementação. Não houve diferença na ingestão de matéria seca pasto entre os períodos de utilização da pastagem, tampouco interação entre as estratégias de alimentação e os períodos.

$\mathrm{O}$ consumo de suplemento diferiu $(\mathrm{P}<0,05)$ entre os períodos de utilização da pastagem e pode ser explicado pelo aumento na quantidade de suplemento fornecido diariamente, decorrente do crescimento das cordeiras ao longo do experimento. A ingestão de concentrado pelas cordeiras sob suplementação com farinha de mandioca representou 33,3\% da ingestão total de MS da dieta e para os animais suplementados com glúten de milho, 37,2\%. A ingestão total média (pasto+suplemento) dos animais representa 2,79\% do peso vivo (PV) no grupo suplementado com farinha de mandioca, a ingestão de MS de pasto participa com $1,86 \%$ do $\mathrm{PV}$. Para as cordeiras que recebiam glúten de milho, a IMS total representa 2,72\% do PV e $1,71 \%$ do PV é proveniente do pasto, enquanto, nos animais mantidos exclusivamente a pasto, a ingestão foi de 2,01\% do PV.

A ingestão de matéria seca total foi influenciada pela suplementação $(\mathrm{P}<0,05)$. Não houve diferença entre as estratégias de suplementação com farinha de mandioca e com glúten de milho ( $\mathrm{P}>0,05)$. A ingestão de MS total foi menor nos animais mantidos exclusivamente em pastagem de milheto, diferindo $(\mathrm{P}<0,05)$ e representando $67,4 \%$ do consumo total dos animais sob suplementação com farinha de mandioca e glúten de milho. Neste trabalho, os animais sob suplementação com glúten de milho apresentaram menor consumo de pasto em relação àqueles exclusivamente em pastagem, resultado que não condiz com dados encontrados por Donaldson et al. (1991), que reportaram que a suplementação proteica para animais em pastejo aumenta o consumo de MS do pasto. Já em trabalhos realizados por Ferrell et al. (2001) e Branco et al. (2004), o fornecimento de fontes de proteína não-degradável no rúmen não alterou o consumo diário de MS proveniente do pasto.

Os animais sob suplementação com glúten de milho apresentaram o menor consumo $(\mathrm{P}<0,05$, Tabela 5) para produzir $1 \mathrm{~kg}$ de peso vivo (PV). Os animais que receberam

Tabela 4 - Ingestão de matéria seca (MS) de pasto, suplementos e ingestão de MS total por cordeiras, em pastagem de milheto (gramas/dia)

\begin{tabular}{lccc}
\hline Item & $\begin{array}{c}\text { Ingestão MS } \\
\text { pasto }\end{array}$ & $\begin{array}{c}\text { Ingestão MS } \\
\text { suplemento }\end{array}$ & $\begin{array}{c}\text { Ingestão MS } \\
\text { total }\end{array}$ \\
\hline Farinha de mandioca & $633,1 \mathrm{ab}$ & $314,6 \mathrm{a}$ & $947,7 \mathrm{a}$ \\
Glúten milho & $570,0 \mathrm{~b}$ & $337,7 \mathrm{a}$ & $907,7 \mathrm{a}$ \\
Milheto & $652,5 \mathrm{a}$ & $0,0 \mathrm{~b}$ & $652,5 \mathrm{~b}$ \\
$\mathrm{~F}$ & 3,84 & 528,82 & 48,84 \\
$\mathrm{P}$ & 0,0342 & $<0,0001$ & $<0,0001$ \\
Períodos (dias) & & & \\
1 a 21 & & & 933,4 \\
22 a 43 & 624,8 & $308,6 \mathrm{~b}$ & 936,2 \\
43 a 64 & 620,7 & $315,5 \mathrm{ab}$ & 964,0 \\
$\mathrm{~F}$ & 609,7 & $354,3 \mathrm{a}$ & 0,12 \\
$\mathrm{P}$ & 0,13 & 4,00 & 0,8878 \\
Interação T $\times \mathrm{P}^{2}$ & 0,8816 & 0,0366 & \\
$\mathrm{~F}$ & & & 1,21 \\
$\mathrm{P}$ & & 0,81 & 9,5302 \\
$\mathrm{CV}$ (\%) & 0,72 & 0,4616 & $0,3,07$ \\
\hline
\end{tabular}

Valores seguidos por letras minúsculas diferentes na mesma coluna diferem $(\mathrm{P}<0,05)$ pelo teste Tukey.

${ }^{1}$ Períodos 1,2 e 3 , respectivamente; ${ }^{2}$ Interação tratamento $\times$ período.

F e P, respectivamente, correspondem a F-teste e significância. 
farinha de mandioca obtiveram resultados intermediários, com diferença significativa $(\mathrm{P}<0,05)$ em relação àqueles que não receberam suplemento.

Em comparação às cordeiras mantidas exclusivamente em pastagem de milheto, aquelas sob suplementação com glúten de milho (pasto + suplemento) tiveram melhor $(\mathrm{P}<0,05)$ conversão alimentar, que foi semelhante à dos animais sob suplementação com farinha de mandioca. As cordeiras que receberam farinha de mandioca e as mantidas exclusivamente a pasto não apresentaram diferença $(P<0,05)$ no consumo de pasto + suplemento para o ganho de $1 \mathrm{~kg}$ de PV. O valor encontrado para a conversão alimentar das cordeiras sob suplementação com glúten provavelmente foi ocasionado pela maior quantidade de aminoácidos que escaparam da fermentação ruminal, suprindo as exigências dos animais (Klopfenstein, 1996).

Os valores de conversão alimentar nos animais sob suplementação com glúten de milho são semelhantes aos relatados por Homem et al. (2007), que observaram valores (6,28 e 5,66 kg de MS para produzir 1 kg de PV) em cordeiros confinados com fornecimento de capim-tifton 85 e suplementação proteica. Rosa et al. (2007) encontraram conversão alimentar em torno de 5,73 em pastagem de Panicum maximum cv Tanzânia mais suplemento proteico.

Apesar de o consumo de suplemento ter sido semelhante entre as cordeiras que receberam glúten de milho e farinha de mandioca (Tabela 4), a degradabilidade ruminal e o teor de PB dos suplementos apresentaram grande diferença, uma vez que a farinha de mandioca apresenta $8,4 \%$ de PB e é 89\% degradável no rúmen e o farelo de glúten de milho $63,4 \%$ de PB e 55\% degradável. Essas diferenças podem ter ocasionado redução no $\mathrm{pH}$ ruminal das cordeiras sob suplementação com farinha de mandioca, reduzindo a digestibilidade do pasto (Coelho da Silva \& Leão, 1979; Hoover \& Stokes, 1991). Além disso, a maior concentração de PB do glúten de milho, aliada à baixa degradabilidade ruminal, pode ter proporcionado melhor utilização de aminoácidos no inestino delgado, proporcionando maior desenvolvimento dos animais (Kozloski, 2002).

Tabela 5 - Conversão alimentar de cordeiras em pastagem de milheto na forma exclusiva ou suplementada com farinha de mandioca ou glúten de milho

\begin{tabular}{lccc}
\hline & \multicolumn{3}{c}{ Conversão alimentar } \\
\cline { 2 - 4 } Estratégia alimentar & Pasto & Suplemento & $\begin{array}{c}\text { Pasto + } \\
\text { suplemento }\end{array}$ \\
\hline Farinha de mandioca & $6,82 \mathrm{~b}$ & 3,38 & $10,21 \mathrm{ab}$ \\
Glúten milho & $4,26 \mathrm{c}$ & 2,53 & $6,79 \mathrm{~b}$ \\
Milheto & $11,07 \mathrm{a}$ & - & $11,07 \mathrm{a}$ \\
CV (\%) & 11,93 & 18,76 & 13,13 \\
\hline
\end{tabular}

Valores seguidos por letras minúsculas diferentes na mesma coluna diferem pelo teste de Tukey $(\mathrm{P}>0,05)$.
Os valores de conversão alimentar encontrados neste trabalho são semelhantes aos descritos por Roma et al. (2007), que relataram valores de 6,3 a 15,5 kg de MS para 1 kg de PV, em pastagem de azevém. Os animais mantidos exclusivamente em pastagem apresentaram melhor conversão alimentar em comparação aos relatos de Castro (2002), que observou valores médios de 25,4 kg de MS para produção de 1 kg de PV em pastagem de milheto.

Observou-se efeito aditivo/substitutivo da suplementação com glúten de milho (Tabela 4), pois houve diminuição na ingestão de MS do pasto, diferindo $(\mathrm{P}<0,05)$ entre os animais que consumiram glúten de milho e aqueles sem suplementação, porém sem modificações na taxa de lotação (Tabela 1). Apesar desse menor consumo de pasto, esses animais apresentaram aumento na ingestão de MS total em comparação aos animais sem suplementação.

Os resultados obtidos por meio das fórmulas descritas por Hodgson (1990) para quantificar os efeitos foram os seguintes: a utilização de glúten de milho como suplemento apresentou efeito substitutivo de 0,22, ou seja, a cada 220 g de glúten de milho consumido, o animal deixa de consumir $1 \mathrm{~kg}$ de MS de pasto. O mesmo efeito ocorreu com a utilização de farinha de mandioca: em 0,4 kg de farinha de mandioca consumida, cordeiras deixaram de consumir $1 \mathrm{~kg}$ de milheto.

Não houve interação estratégias alimentares $\times$ períodos para o ganho médio diário de peso (GMD) que variou $(\mathrm{P}<0,05)$, no entanto, entre as estratégias de alimentação. A suplementação com glúten de milho apresentou os melhores resultados, diferindo das demais estratégias alimentares, que foram semelhantes $(\mathrm{P}>0,05)$. Os animais que receberam glúten de milho apresentaram ganho médio diário (GMD) de em média $0,133 \mathrm{~kg}$, sendo este valor $54 \%$ superior ao GMD das cordeiras sob suplementação com farinha de mandioca, que apresentaram 0,096 kg/dia e foram $82 \%$ superior aos animais mantidos exclusivamente na pastagem de milheto, com ganho médio diário de $0,072 \mathrm{~kg}$.

Houve diferença $(\mathrm{P}<0,05)$ no ganho total de peso durante o período experimental (diferença entre peso inicial e final), pois, nos animais sob suplementação com glúten de milho (GL), o ganho total foi de 8,9 kg, superior $(\mathrm{P}<0,05)$ aos observados nas demais estratégias alimentares. $\mathrm{O}$ ganho total de peso das cordeiras que consumiram farinha de mandioca foi $36 \%$ inferior ao dos animais que receberam glúten de milho (5,7 kg), que, por sua vez, foi $45 \%$ superior ao dos animais que não receberam suplemento. Os animais sob suplementação tiveram ganhos semelhantes $(\mathrm{P}>0,05)$.

Os animais mantidos exclusivamente em pastagem apresentaram dois ciclos principais de pastejo ao longo do dia (Figura 1). O primeiro teve início nas primeiras horas do 
dia (em torno das $7 \mathrm{~h}$ ), com pico em torno das $9 \mathrm{~h}$, e estendeu-se até às11 h. O segundo ciclo de pastejo ocorreu no período da tarde, com início em torno das 15 horas e pico aproximadamente às $17 \mathrm{~h}$, estendendo-se até por volta das 19 h. Os animais sob suplementação com farinha de mandioca e glúten de milho recebiam o suplemento diariamente às 9 h e apresentaram diminuição do tempo de pastejo durante o ciclo da manhã, ocasionado pelo tempo gasto para consumir os suplementos.

Os resultados obtidos sugerem que práticas de manejo, como suplementação dos animais em pastagens, devem ser feitas entre 12 e $14 \mathrm{~h}$, assim, seriam respeitados os principais horários de pastejo, em termos quantitativos (início da manhã e final de tarde). Rovira (1997), referindo-se ao comportamento ingestivo de bovinos, não recomendou suplementação aos animais nas primeiras horas da manhã, pois, em vez de complementar, estar-se-ia substituindo a dieta disponível na pastagem pelo suplemento fornecido.

Em trabalho realizado por Medeiros et al. (2007), os animais apresentaram início do pastejo em torno das $7 \mathrm{~h}$ e no período da tarde, a partir das $16 \mathrm{~h}$, o que foi confirmado por Starling et al. (1999). Resultados semelhantes foram encontrados neste trabalho, com períodos de pastejo entre 8 e 11 h e das 16 às 19 h.

A maior porcentagem de pastejo dos animais ocorreu no período diurno, entre 6 e 20 h. Os animais sob suplementação com farinha de mandioca ou glúten de milho e aqueles mantidos exclusivamente em pastagem apresentaram, respectivamente, 80,9; 83,1 e 81,1\% do tempo total de pastejo diário entre 6 e 20 h. À noite, entre 20 e 6 h, os animais sob suplementação com farinha de mandioca pastejaram 19,1\% do tempo (85 $\mathrm{min}$ ), aqueles sob suplementação com glúten de milho 23,6\% (102 min) e aqueles mantidos exclusivamente em pastagem, 18,9\% (97 min). É possível que o pastejo noturno tenha sido estimulado pelas temperaturas nas datas das avaliações de comportamento, cujos valores médios foram de $24,3{ }^{\circ} \mathrm{C}$ em 12 e 13/02/06; 05 e 06/03/06; 26 e 27/03/06. Segundo Pedroso et al. (2004), em dias quentes, os ovinos podem ser estimulados a pastejar no período noturno para satisfazer suas exigências de ingestão de MS.

Independentemente da estratégia alimentar, as cordeiras realizaram pastejo mais intenso no período da tarde (das 12 às $20 \mathrm{~h}$ ) apresentaram maiores tempos de pastejo nesse período (Figura 1). Os animais que consumiam farinha de mandioca distribuíram o pastejo em 37\% no período da manhã e $63 \%$ no período da tarde. As cordeiras que receberam glúten de milho, $41 \%$ na manhã e $59 \%$ no período da tarde e os animais exclusivamente a pasto, $45 \%$ na manhã e 55\% à tarde. O horário de suplementação coincidiu com o pico de pastejo dos animais que não receberam suplemento, o que pode ter ocasionado os menores tempos de pastejo no período da manhã em comparação ao tempo gasto pelos animais no período da tarde.

O aumento no tempo de pastejo no final do dia para todas as estratégias alimentares pode ser atribuído à composição química das plantas, que apresentam os maiores teores de MS e carboidratos nestes horários (Orr et al., 1997; Barbosa et al., 2010). Parsons et al. (1994), em trabalho sobre o comportamento de ovinos durante 24 horas em pastagens de azevém e trevo-branco, acrescentaram que a maior ingestão de forragem ao final da tarde ocorre porque os animais dispõem do período noturno para a atividade de ruminação.



Horas do dia

Figura 1 - Distribuição do pastejo dos animais durante 24 horas de observação em pastagem de milheto. 


\section{Conclusões}

Cordeiras que não recebem suplemento permanecem mais tempo em pastejo. O fornecimento de farinha de mandioca para cordeiras mantidas em pastagem de milheto na fase da recria modifica a estratégia de colheita de pasto, diminuindo o tempo diário de pastejo e a taxa de bocados. Essa mudança implica aumento na massa de bocado, mas não altera o consumo diário de matéria seca proveniente do pasto. A suplementação aos animais deve ser realizada fora dos períodos de pastejo intenso para que não ocorra diminuição no tempo de pastejo durante o dia.

\section{Referências}

ADJEI, M.B.; MISLEVI, P.; WARD, C.Y. Response of tropical grasses to stocking rate. Agronomy Journal, v.72, p.863868, 1980.

ASSOCIATION OF OFFICIAL ANALITICAL CHEMISTRY AOAC. Official methods of analysis. 16.ed. Arlington: AOAC International, 1995. 1025p.

BARBOSA, C.M.P.; CARVALHO, P.F.C.; CAUDURO, G.F. et al. Componentes do processo de pastejo de cordeiros em azevém sob diferentes intensidades de pastejo. Archivos de Zootecnia, v.59, n.225, p.39-50, 2010.

BARTON, R.K.; KRYSL, M.B.; JUDKINS, D.W. et al. Time of daily supplementation for steer grazing dormant intermediate wheatgrass pasture. Journal of Animal Science, v.70, n.2, p.547-558, 1992.

BRANCO, A.F.; MOURO, G.F.; HARMON, D.L. et al. Fontes de proteína, ingestão de alimentos e fluxo esplâncnico de nutrientes em ovinos. Revista Brasileira de Zootecnia, v.33, n.2, p.444452, 2004.

BREMM, C.; SILVA, J.H.S.; ROCHA, M.G. et al. Comportamento ingestivo de ovelhas e cordeiras em pastagem de azevém-anual sob níveis crescentes de suplementação. Revista Brasileira de Zootecnia, v.37, n.12, p.2097-2106, 2008.

CARVALHO, P.C.F; RIBEIRO FILHO, H.M.N; POLI, C.H.E.C. et al. Importância da estrutura da pastagem na ingestão e seleção de dietas pelo animal em pastejo. In: REUNIÃO ANUAL DA SOCIEDADE BRASILEIRA DE ZOOTECNIA, 38., 2001, Piracicaba. Anais... Piracicaba: FEALQ, 2001. p.853-871.

CASTRO, C.R.C. Relações planta-animal em pastagem de milheto (Pennisetum clandestinum (L.) Leeke) manejadas em diferentes alturas com ovinos. 2002. 200f. Dissertação (Mestrado em Zootecnia) - Universidade Federal do Rio Grande do Sul, Porto Alegre.

COELHO DA SILVA, J.F.; LEÃO, M.I. Fundamentos da nutrição dos ruminantes. Piracicaba: Livroceres, 1979. 384p.

CZARNOCKI, J.; SIBBALD, D.R.; EVANS, E.V. The determination of chromium oxide in samples of feed and excreta by acid digestion and spectrophotometry. Canadian Journal of Animal Science, v.4, p.167-179, 1961.

DONALDSON, R.S.; MCCANN, M.A.; AMOS, H.E. et al. Protein and fiber digestion by steers grazing winter annuals and supplemented with ruminal escape protein. Journal of Animal Science, v.69, n.7, p.3067-3071, 1991.

EMPRESA BRASILEIRA DE PESQUISA AGROPECUÁRIA EMBRAPA. Centro nacional de pesquisa de solos. Sistema brasileiro de classificação de solos. Rio de Janeiro: EMBRAPA, 1999. 412p.

FERRELL, C.L.; FREETLY, H.C.; GOETSCH, A.L. et al. The effect of dietary nitrogen and protein on feed intake, nutrient digestibility, and nitrogen flux across the portaldrained viscera and liver of sheep consuming highconcentrate diets ad libitum. Journal of Animal Science, v.79, p.1322-1328, 2001.

FORBES, T.D.A. Researching the plant-animal interface: the investigation of ingestive behavior in grazing animals. Journal of Animal Science, v.66, p.2369-2379, 1988.

GARDNER, A.L. Técnicas de pesquisa em pastagens e aplicabilidade de resultados em sistemas de produção. Brasília: IICA/EMPBRAPA-CNPGL, 1986. 197p. (IICA, Série Publicações Miscelâneas, 634).

GOERING, H.K.; VAN SOEST, P.J. Forage fiber analysis (apparatus, reagents, procedures and some applications). Washington, D.C.: Agricultural Research Service, 1970. 20p. (Agricultural Handbook, 379).

HANCOCK, J. Grazing behaviour of cattle. Animal Breeding Abstract, v.21, n.1, p.1-13, 1953.

HERINGER, I.; CARVALHO, P.C.F. Ajuste da carga animal em experimentos de pastejo: uma nova proposta. Ciência Rural, v.32, n.4, p.675-679, 2002.

HODGSON, J. Grazing management. Science into practice. England: Longman Scientific \& Technical, 1990. 203p.

HODGSON, J. Ingestive behavior. In: LEAVER, J.D. (Ed.) Herbage intake handbook. Hurley: British Grassland Society, 1982. p.113.

HODGSON, J. The control of herbage intake in the grazing ruminant. Proceedings of the Nutrition Society, v.44, p.339-346. 1985.

HOMEM, A.C.; SOBRINHO, A.G.S.; YAMAMOTO, S.M. et al. Ganho compensatório de cordeiras na fase de recria: Desempenho e medidas biométricas. Revista Brasileira de Zootecnia, v.36, n.1, p.111-119, 2007.

HOOVER, W.H.; STOKES, S.R. Balancing carbohydrates and proteins for optimum rumen microbial yield. Journal of Dairy Science, v.74, n.10, p.3630-3644, 1991.

ILLIUS, A.W.; JESSOP, N.S. Metabolic constraits on voluntary intake in ruminants. Journal of Animal Science, v.74, p.3052-3062, 1996.

JAMIESON, W.S.; HODGSON, J. The effect of daily herbage allowance and sward characteristics upon the ingestive behavior of calves under strip-grazing management. Grass and Forage Science, v.34, p.261-271, 1979.

KLINGMAN, D.L.; MILES, S.R.; MOTT, G.O. The cage method for determining consumption and ield of pasture herbage. Journal of American Society of Agronomy, v.35, p.739746, 1943.

KLOPFENSTEIN, T. Need for scape protein by grazing catle. Animal Feed Science and Tecnology, v.60, p.191-199, 1996.

KOZLOSKI, G. V. Bioquímica dos ruminantes. 1.ed. Santa Maria: Universidade Federal de Santa Maria, 2002. v.1, 140p.

KRYSL, L.J.; HESS, B.W. Influence of supplementation on behavior of grazing cattle. Journal of Animal Science, v.71, p.25462555, 1993

MALAN, F.S.; VAN WYK, J.A. The packed cell volume and color of the conjunctivae as aids for monitoring Haemonchus contortus infestations in sheep. In: BIENNIAL NATIONAL VETERINARY CONGRESS, 1., 1992, Grahamstown, África do Sul. Anais... Grahamstown: South African Veterinary Association, 1992. v.1. p.139.

MEDEIROS, R.B.; PEDROSO, C.E.S.; JORNADA, J.B.J. et al. Comportamento ingestivo de ovinos no período diurno em pastagem de azevém anual em diferentes estádios fenológicos. Revista Brasileira de Zootecnia, v.36, n.1, p.198-204, 2007.

MORENO, J.A. Clima do Rio Grande do Sul. Porto Alegre: Secretaria da Agricultura, 1961. 41p.

MOTT, G.O.; LUCAS, H.L. The design, conduct and interpretation of grazing trials on cultivated and improved pastures. In: INTERNATIONAL GRASSLAND CONGRESS, 6., 1952, Pennsylvania. Proceedings... Pennsylvania: SCP, 1952. p.1380-1395.

NEWMAN, J.A.; PARSONS, A.J.; PENNING, P.D. A note on the behavioral strategies used by grazing animals to alter their intake rates. Grass and Forage Science, v. 49, p. 502-505, 1994. 
ORR, R.J.; PENNING, P.D.; HARVEY, A. et al. Diurnal patterns of intake rate by sheep grazing monocultures of ryegrass or white clover. Applied Animal Behavior Science, v.52, p.65-77, 1997.

PARENTE, H.N.; ZANINI, A.M.; SANTOS, E.M. et al. Comportamento ingestivo de ovinos em pastagem de Tifton85 (Cynodon ssp) na região nordeste do Brasil. Revista Ciência Agronômica, v.38, n.2, p.210-215, 2007.

PARSONS, A.J.; NEWMAN, J.A.; PENNING, P.D. et al. Diet preference of sheep: effects of recent diet, physiological state and species abundance. Journal of Animal Ecology, v.63, p.465-478, 1994

PEDROSO, C.E.S; MEDEIROS, R.B.; SILVA, M.A. et al. Comportamento de ovinos em gestação e lactação sob pastejo em diferentes estágios fenológicos de azevém anual. Revista Brasileira de Zootecnia, v.33, n.5, p.1340-1344, 2004.

POPPI, D.P. Nutrition of the lamb after weaning. In: FAMILTON, A.S. (Ed.). Lamb growth. Lincoln College: [s.n.], 1983. p.29-2. (Farmers Handbook)

PRACHE, S.; PEYRAUD, J. Préhensibilité de l'herbe pâturée chez lês bovins et lês ovins. INRA Productions Animales, v.10, p.377-390, 1997.

PROVENZA, F.D.; LAUCHBAUNGH, K.L. Foraging on the edge of chaos. In: LAUCHBAUNGH, K.L.; MOSLEY, J.C.; SANDERS, K.D. (Eds.). Grazing behavior of livestock and wildlife. Moscow: University of Idaho, 1999. p.1-12.

RATTRAY, P.V.; THOMPSON, K.F.; HAWKER, H. et al. Pastures for sheep production. In: NICOL, A.M. (Ed.). Livestock feeding on pasture. New Zealand Society of Animal Production, 1987. p.89-104.
ROMAN, J.; ROCHA, M.G.; PIRES, C.C. et al. Comportamento ingestivo e desempenho de ovinos em pastagem de azevém anual (Lolium multiflorum Lam.) com diferentes massas de forragem. Revista Brasileira de Zootecnia, v.36, n.4, p.780-788, 2007.

ROSA, G.T.; SIQUEIRA, E.R.; GALLO, S.B. et al. Influência da suplementação no pré-parto e da idade da desmama sobre o desempenho de cordeiros terminados em confinamento. Revista Brasileira de Zootecnia, v.36, n.4, p.953-959, 2007.

ROVIRA, J. Manejo nutritivo de los rodeos de cria en pastoreo. Montevideo: Hemisferio Sur, 1997. 288p.

SCREMINI, P.; CASTELS, D.; MORLÁN, J.B. Enfermedades de los lanares, tomo II. Montevideo: Hemisferio Sur, 1981. p221-227.

STATISTICAL ANALYSIS SYSTEM - SAS. Statistical analysis system user's guide. Version 8.2 Cary: SAS Institute, 2001. 943p.

STARLING, J.M.C.; SILVA, R.G.; COSTA, M.J.R.P. et al. Comportamento de pastejo de ovinos em ambiente tropical. In: REUNIÃO ANUAL DA SOCIEDADE BRASILEIRA DE ZOOTECNIA, 41., 1999, Porto Alegre. Anais... Porto Alegre: Sociedade Brasileira de Zootecnia, 1999. (CD-ROM).

TILLEY, J.M.A.; TERRY, R.A. A two-stage technique for the in vitro digestion of forage crop. Journal of British Grassland Society, v.18, n.2, p.104-111, 1963.

UNGAR, E.D.; GENIZI, A.; DEMMENT, M.W. Bite dimensions and herbage intake by cattle grazing short hand-constructed swards. Agronomy Journal, v.83, p.973-978, 1996.

VAN SOEST, P.J. Nutritional ecology of the ruminant. 2.ed. Ithaca: Cornell. 1994. 476p. 